\title{
Is Kumasi Still a Garden City? Land Use Analysis between 1980-2010
}

\author{
Collins Adjei Mensah \\ Centre for Urban and Regional Studies \\ School of Geography, Earth and Environmental Sciences \\ University of Birmingham (UK), B15 2TT \\ $\&$ \\ Department of Geography and Regional Planning \\ University of Cape Coast, Ghana \\ Tel: 447-4665-78385Ｅ-mail: collinsadjeimensah@gmail.com
}

Received: July 13, 2014 Accepted: August 13, $2014 \quad$ Published: October 14, 2014

doi:10.5296/jee.v5i2.5968ＵRL: http://dx.doi.org/10.5296/jee.v5i2.5968

\begin{abstract}
Preserving natural environment in the physical landscape of cities is an important component of the garden city model. It helps to maintain ecological balance between nature and human activities. This paper sought to assess the garden city status of Kumasi (Ghana) from the perspective of available green vegetation (green spaces). Using a case study research strategy, archival records (such as Landsat satellite images), documentary data and personal observations constituted the sources of data for the study. It was found out that Kumasi has lost most of its green vegetation to housing developments and commercial activities. The city's preserved green belts have become vacant, most of the parks and gardens are no more with many of the remaining parks converted into commercial centres. Urban sprawl was also very prevalent causing excessive loss of green vegetation at the fringes of the city. Kumasi now lacks enough green vegetation which is contrary to the garden city model that the city was built on. It is therefore recommended that conservation of the green vegetation should be made a priority by the city authorities with appropriate green space strategy put in place to guide the development of the city's green spaces.
\end{abstract}

Keywords: Garden city, Green vegetation, Parks, Gardens, Kumasi 


\section{Introduction}

Integrating green spaces such as parks, gardens, trees, and forest into the physical landscape of cities is very important in urban planning. This is due to the immense benefits that these spaces offer to urban environment such as enhancing recreational needs of urban dwellers, ameliorating local climate, improving urban air quality, supporting the development of children, and promoting social cohesion and interaction (Baycan-Levent et al., 2009; Fam et al., 2008). Many urban planning theories therefore have preservation of green spaces embedded in their framework to serve as a means to support the sustainability of cities and also help urban dwellers to easily tap the benefits associated with the green vegetation. Among such theories are the garden city, eco-city, green urbanism, smart growth, compact city, and currently biophilic city. Recent development pattern of urban areas observed by the United Nations (2012) found rapid urbanisation as a critical problem with the resultant effect being destruction of much green vegetation to make way for the increasing population. This situation has raised much concern about urban dwellers now becoming disconnected from the natural environment which is supposed to be readily available to support their health and wellbeing (Kabisch \& Haase, 2014; Goddard et al, 2010; Fuller \& Gaston, 2009). This deteriorating condition in urban areas was among the core reasons that necessitated the development of the garden city model in the late $19^{\text {th }}$ Century by Ebenezer Howard as a means to conserve much of the natural environment to create a mixture of town and country (village) life in an urban setting (Howard, 1902).

Kumasi is one of the few cities in Africa that enjoyed the application of the garden city model from its colonial masters who were the British. Following the defeat of the Ashanti people in a war by the British merchants at Kumasi (Ghana) in 1896, the whole city was raised down and rebuilt at the same location by the British (Schmidt, 2005). The 1945 development plan for Kumasi prepared by the British (Maxwell Fry and Jane Drew) followed the Garden city model which was popular at that time and allocated substantial part of the city's land area to green spaces. These green spaces literally cover all public and private open spaces in urban areas mostly covered by natural vegetation which are directly or indirectly available for human usage. Examples of such spaces in Kumasi during that period were urban parks, gardens, trees, forest, wetlands and green belts. Subsequent development of the city followed similar pattern with much green spaces been preserved in the city's physical landscape. This situation made the city to gained the accolade the garden city of West Africa in the 1960s (Asare, 2013; Quagraine, 2013). However, recent development in Kumasi such as excessive urban sprawl taken place in the city's fringes and much physical alteration of the green vegetation now raise questions about the garden city status of the city. This is because much green spaces which are supposed to be available to support the garden city model are now being depleted at an alarming rate. One basic question often comes to mind in connection with this problem. Does Kumasi have enough green vegetation to still make it a garden city?

Although numerous studies have been carried out on Kumasi but much attention have not been directed to the above question and the overall status of green vegetation in the land-use structure of Kumasi. It is therefore to bridge this knowledge gap that this paper was put together to find out whether Kumasi still has enough green vegetation to be called a garden 
city. The current paper assesses the garden city status of Kumasi from the perspective of only green vegetation but not the overall design of the garden city model. The paper provides significant contributions in diverse ways. It provides much insight and analysis about the changes that have taken place in the green vegetation of Kumasi. It gives accurate conclusions about the current state of Kumasi's green vegetation which is expected to serve as guidance to the Kumasi city authorities in their decisions about the future development agenda of the city. The paper also expands the existing literature on the garden city model by bringing on board the situation of Kumasi to serve as reference for future studies undertaken in similar context. Furthermore, the paper provide good lessons to policy makers and city authorities elsewhere (especially garden cities) to take inform decisions to preserve the green vegetation of their cities from persistent deterioration.

\section{The Garden City Model with Much Reference to Green Vegetation}

Technological innovations coupled with economic and social conditions at the end of the Eighteenth Century contributed largely in speeding up industrialization in Western Europe, especially in Great Britain, which by the middle of the Nineteenth Century became the leading industrial country in the world (Corovic, 2009). The industrialization influenced mass movement of people into cities causing overcrowding and a general poor health condition in many cities (Harris, 1906). The garden city ideology by Ebenezer Howard (1850-1929) was introduced to solve social and health problems that were brought up by the industrial revolution. He elaborated this model in his book entitled "tomorrow: a peaceful path to real reform" which was first published in 1898 and later revised in 1902 under the title "the garden cities of tomorrow" (Hall, 2002). In theorising the garden city model, Howard (1902) noted that to address the unhealthy lifestyles in cities, town and country (village) must be married (integrated) and out of this union will spring off a third magnet (garden city) which will provide a new hope and life. Howard remarked as follows:

There are in reality not only as is so constantly assumed, two alternatives - town life and country life - but a third alternative in which all the advantages of the most energetic and active town life with all the beauty and delight of the country may be secured in perfect combination; .... the Town-Country which are seen to be free from the disadvantages of either (Howards, 1902:8-10).

According to the garden city model, both cities and countryside have unique qualities that attract people to them. For the countryside, the beauty of nature, fresh air, sunshine, and the fruits of the earth are the magnets pulling people to the land whilst cities on the other hand attract people as a result of opportunities such as employment, hopes of advancement, social enrichment, higher wages, and cultural activities (Clark, 2003). The proposed third magnet (garden city) combines the "energetic and active town life with all the beauty and delight of the countryside" without the negatives of either town or countryside (Howard, 1902: 15-17). In principle, the garden city model was to bridge the gap separating the existence of society and the natural environment (Sandstrom, 2009). Howard (1902) wanted the garden city to have a hybrid of city and countryside advantages and he conceptualised this using three magnets (Figure 1). 


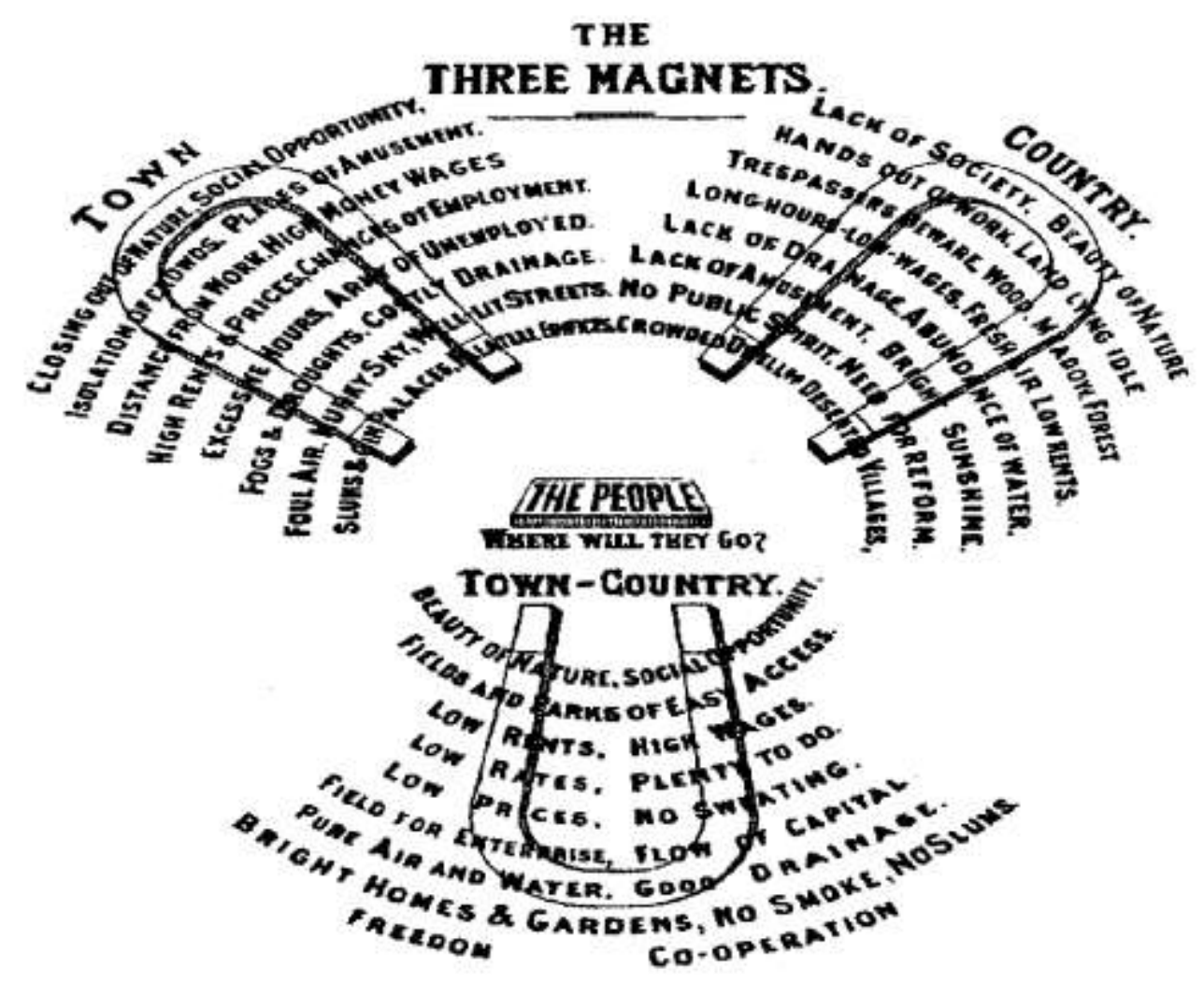

Figure 1. Ebenezer Howard's three magnets

Source: Ebenezer Howard (1902)

The structure of the garden city put forward by Howard (1902) had much of the land area (over $60 \%$ ) occupied by green vegetation. This made the green vegetation a unique feature of the garden city model. The overall land area for the garden city was estimated to cover 6000 acres of undeveloped agricultural land with the city occupying 1000 acres near the centre of the whole land mass (Figure 2). The city was to accommodate an estimated population of about 32,000 people. The remaining 5000 acres of agricultural land surrounding the city was to serve as green belt and a boundary between the city and its countryside (Clark, 2003; Ward, 1992). This green belt was to check urban sprawl and also to be used for purposes such as allotments, pastures, large farms, forests, orchards, and open space for recreation (Howard, 1902). 

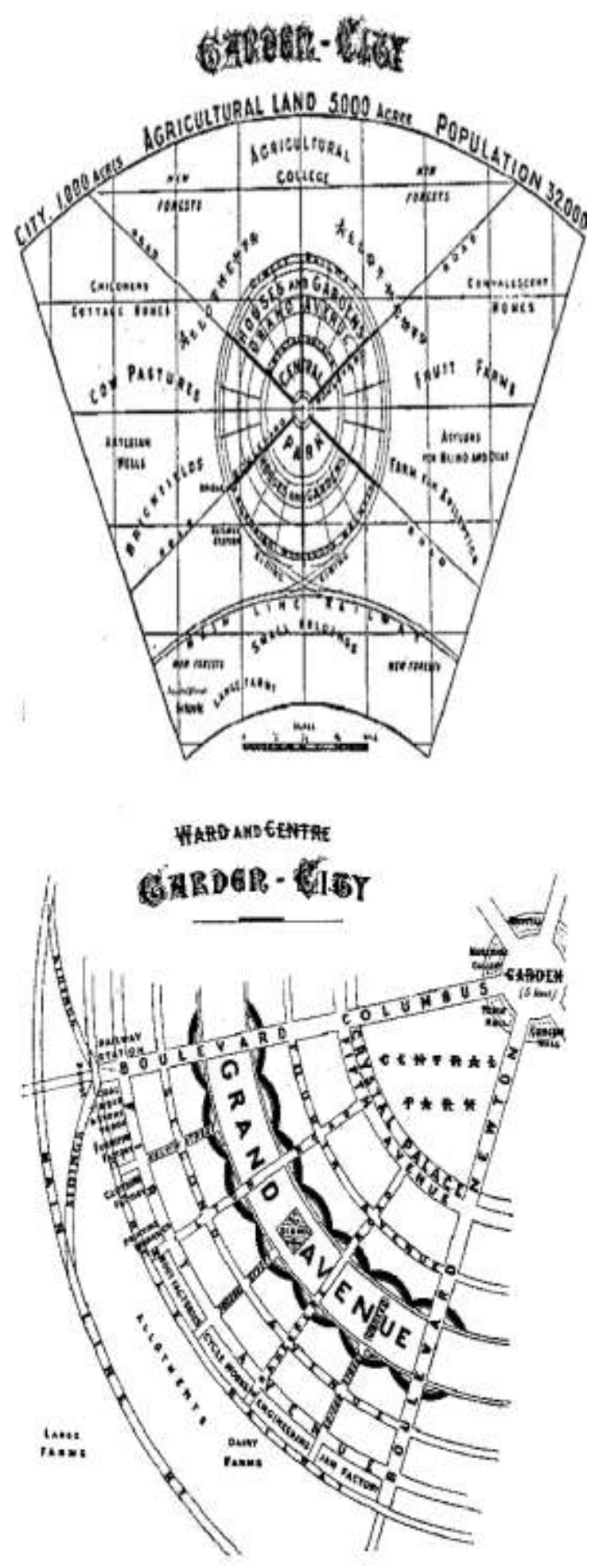

Figure 2. The garden city land structure

Source: Ebenezer Howard (1902)

The garden city was divided by 6 magnificent boulevards (each 120 feet wide) which traversed from the centre to the circumference of the city with the centre of the city occupied by a public garden. Surrounding the public garden are large public buildings such as city hall, 
libraries, museums, hospitals, concert halls, and theatres serving as a central point for the public to come together. Following the public buildings is a large created public park to provide recreational avenue for the city dwellers. A crystal palace (wide glass arcade) surrounds the public park and at this location there is open-air market and exhibition space for trading of manufactured and agricultural goods. Another important feature of the garden city model was a series of road network in a form of concentric rings which provide avenues for several blocks of residential housing. The roads are supposed to be lined with trees whilst the houses ought to have ample spaces for gardens so as to integrate homes into the natural setting of the garden city. Another conspicuous feature of garden city was Grand Avenue and this provided additional parks for the urban dwellers. On the Grand Avenue were erected churches, school buildings and a series of parks and gardens. The outer ring or outskirt of Howard's garden city (Figure 2) provided land allocation for factories, warehouses, dairies, markets, timber yards and a railway line which was to provide easy transport of goods between industries and also reduce traffic in the city (Clark, 2003).

The overall layout or plan of the garden city favours integration of much green vegetation into city's land area than other land uses. Mumford (1972) saw this as a perfect land use combination and stressed that the garden city model offers a major criteria for dynamic equilibrium and organic balance. That is a balance between countryside and city in a broader ecological pattern, and a balance between the built and natural environment. Similarly, the Town and Country Planning Association (2014) indicated that the garden city model offers opportunity to enhance human development through much contact with the natural green vegetation. Such enhancement is gained through designed homes in gardens to promote healthy living, availability of enough shared parks and gardens for social interaction, sports and leisure activities. The numerous benefits attached to the garden city model such as enhancing the health, convenience and beauty of cities resulted in its successful applications in many cities across the world. Cities where garden city principles have been applied include Letchworth and Welwyn (first sets of garden cities, UK), Singapore, Melbourne (Australia), Putrajaya (Malaysia), and Kumasi (Ghana). In all these cities, green vegetation is expected to occupy substantial part of the total land area and also much of the physical development of the city is expected to be interspersed by the green vegetation.

\section{Materials and Methods}

The paper focused on Kumasi which is located in the transitional forest zone of Ghana and can be found about $270 \mathrm{~km}$ north of Accra the national capital (Figure 3). It lies between latitude $6.35^{\circ}-6.40^{\circ}$ and longitude $1.30^{\circ}-1.35^{\circ}$, an elevation which ranges between $250-$ 300 metres above sea level (Kumasi Metropolitan Assembly [KMA], 2010). It has a total land area of approximately $254 \mathrm{~km}^{2}$. The 2010 Population and Housing Census of Ghana put the total population of Kumasi at 2,035, 064 people and it also has an estimated annual population growth rate of 5.4 per cent (Cobbinah \& Amoako, 2012; Ghana Statistical Service, 2012). The city falls within the moist semi-deciduous vegetation zone of Ghana which has favourable soil conditions that support green vegetation and farming activities. 


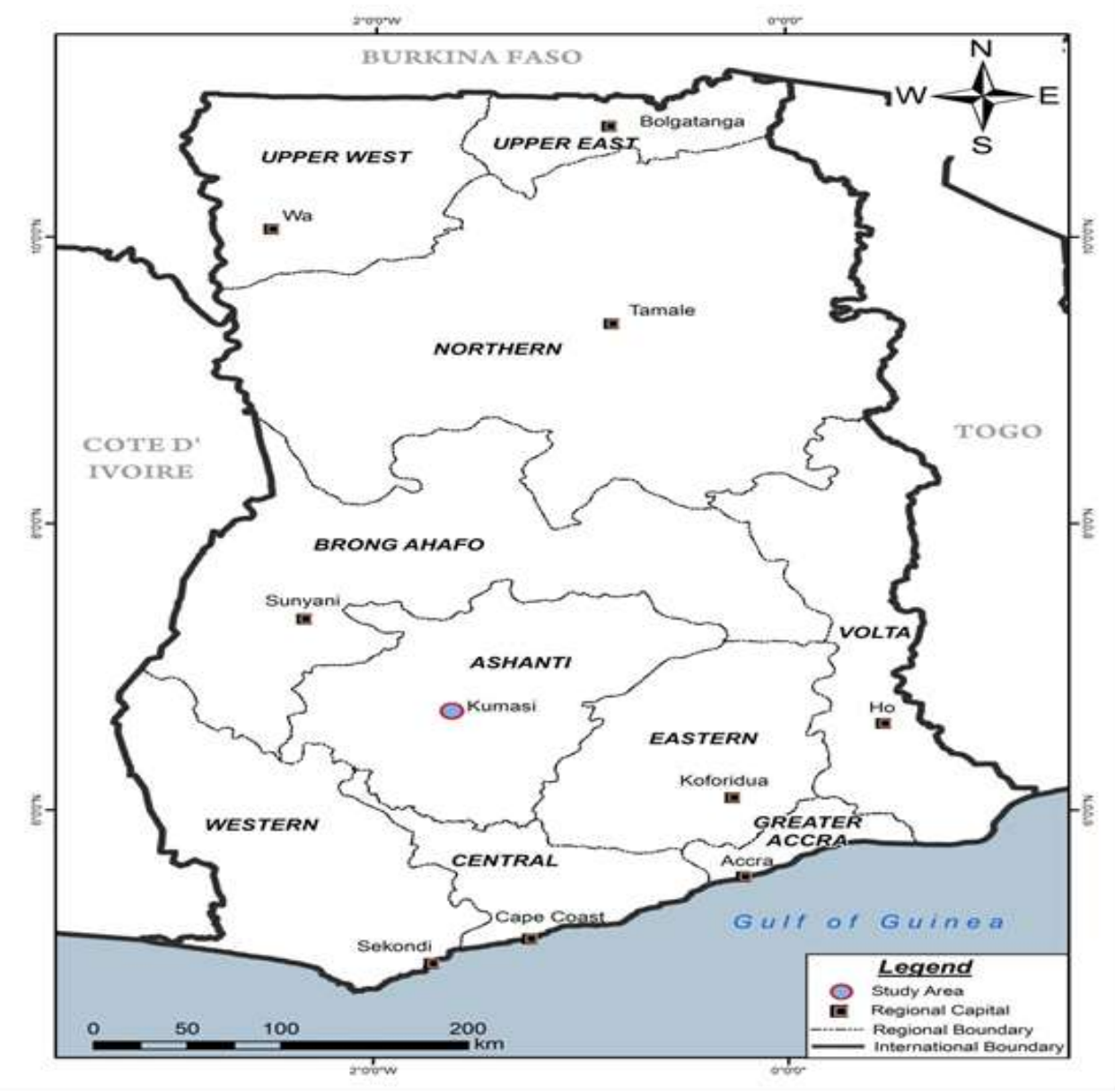

Figure 3. Map of Ghana showing the location of Kumasi

Source: Department of Geography and Regional Planning, University of Cape Coast (Ghana) (2013).

The case study research strategy was employed in this study. This research strategy investigates a contemporary phenomenon within its real-life context so as to have in-depth understanding of the topic understudy (Yin, 2009). Woodside (2010) defined case study as an inquiry that focus on describing, understanding, predicting and controlling a phenomenon to have much knowledge of that particular phenomenon with emphasis not only on contemporary issues. This approach was therefore adopted in the current study to have broader overview and understanding of the structure of green vegetation in the land distribution of Kumasi. To have in-depth information and draw accurate conclusions, case studies use multiple sources of data (Yin, 2003). In line with this principle, different sources of data were relied upon in the current study. These were archival records, documentary data and personal observations. These sources of data were settled on due to the nature of the study which demanded historical accounts and facts from wide range of documents as well as first-hand information to know the true condition of the green vegetation of Kumasi. The archival data utilised were satellite images (Landsat TM) on land cover change of Kumasi from 1986 to 2010, historical accounts on the green vegetation, and land use structure of Kumasi from 1988 to 2010 . The Landsat satellite images provided easy visual identification 
and factual information on the changes that have taken place in the green vegetation of the study area. The documentary data included the development plan of Kumasi (2010-2013) and publications on the city's green vegetation. The data from personal observation were obtained from a series of personal observation sessions that were carried out by the researcher to personally observe the current state of some of the major parks and gardens in Kumasi. These sources of data helped to gather much information to establish a chain of evidence about the current state of the green vegetation of Kumasi.

\section{Results and Discussion}

This section of the paper is structured into four broad themes: landscape of Kumasi before 1980, land cover change between 1980 and 2010, land-use trend in Kumasi between 1980 and 2010, and the current situation of parks and gardens. This was done to provide well organised discussion and easy understanding of the topic understudy for informed conclusions to be drawn.

\subsection{Landscape of Kumasi before 1980}

The findings of the paper found that Kumasi had much green vegetation before 1980. The 1945 plan of the city designed by Maxwell frye and Jane Drew structured the development of the city on the garden city model which was much popular among the western world at that time (Quagraine, 2011). It was further revealed that the 1963-1988 planning scheme of Kumasi which its implementation started in the 1960s allocated about 40percent of the city's land reserve (20, 000 hectares) to open spaces and agricultural development (Adarkwa \& Owusu-Akyaw, 2001). Archival records revealed that based on Frye and Drew's plan in 1945, Kumasi had a notable green belt (330 yard-wide) which coincided with river tributaries that transect the city through neighbourhoods such as Atonsu, Kaasi, Bantama, and Aboabo (Curtin, 1992; Dinye et al., 1987; Town Planning Memorandum, 1951).

There were numerous parks and gardens that interspersed physical developments and also beautify the overall landscape of Kumasi. These green spaces provided different functions to satisfy the recreational needs of the local people and improved the health condition of the city as well. Five planed urban parks were first created during the colonial period and positioned at vantage points. These were "Kejetia" Park (Adehyeman gardens), Suntreso Park (at the premises of Department of Parks and Gardens), park at "Amakom” (now Kumasi Children's Park), Fante Newtown Park, and Kumasi Zoological Gardens (Kumasi Zoo). The Suntreso Park was renowned for containing a stream corridor similar to the English parks at that time as stressed by Dinye et al. (1987). After these parks, it was noticed that several other parks and gardens were created to serve the growing population of the city. Notable among them were Abbey's Park, Jackson Park, Prince of Wales Park, Para Gardens and Kumasi Race Course. Others were the Kotoko Park (also known as Cricket) behind the Manhyia Hospital; the Addo's Park behind the Manhyia Palace; the Dogo Moro Park at "Asawase"; and the Rivoli Park at "Bantama” (Asare, 2013).

Walking through the principal streets of Kumasi was a delight to watch as one will observe beautiful scenery of decorated urban trees and lawns at the central business district. There 


\section{Macrothink}

were a variety of trees along many principal streets of Kumasi which formed canopy and shade for travellers and pedestrians. Typical examples were trees along roads joining "Asarfo" and "Tech" Neighbourhoods, and "Danyame" and "Patasi Neighbourhoods" (Adjei Mensah, 2014). The central business district had several shrubs and lawns which made the commercial hub of the city greener. Neighbourhoods such as Ahodwo, Nhyiaso and Patasi were also noted for harbouring rich stock of nature reserves and green vegetation (Adjei Mensah, 2014). All these green spaces formed the green infrastructure of Kumasi which made the city one of the greenest cities in Africa and a point of attraction for both local and foreign tourists.

\subsection{Land Cover Change between 1980 and 2010}

The available Landsat satellite images captured on Kumasi during this period showed that the city has lost substantial part of its lands preserved for green vegetation to the built environment land cover type. For example, it was observed from Koranteng's (2007) study (land use/land cover of Kumasi and its environs using Landsat images) that much of the green vegetation of Kumasi in 1986 were converted to housing developments by 2003 which expanded outwards from the city centre to the periphery (Figure 4b).

(a)

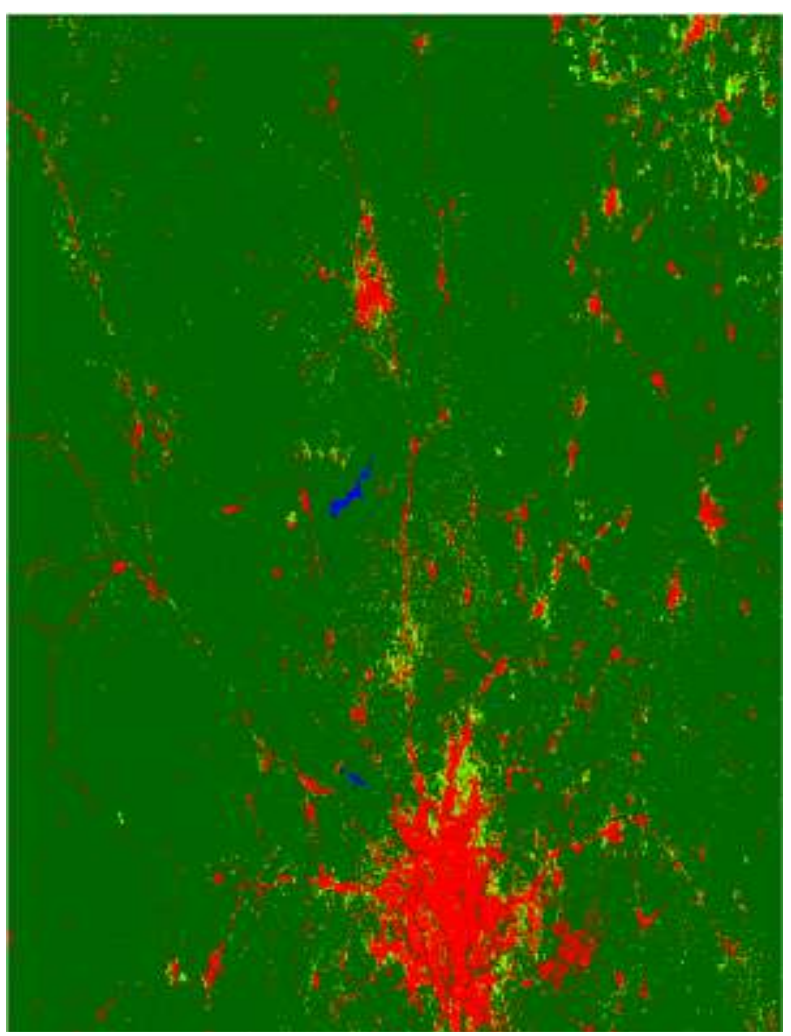

1986 (b)

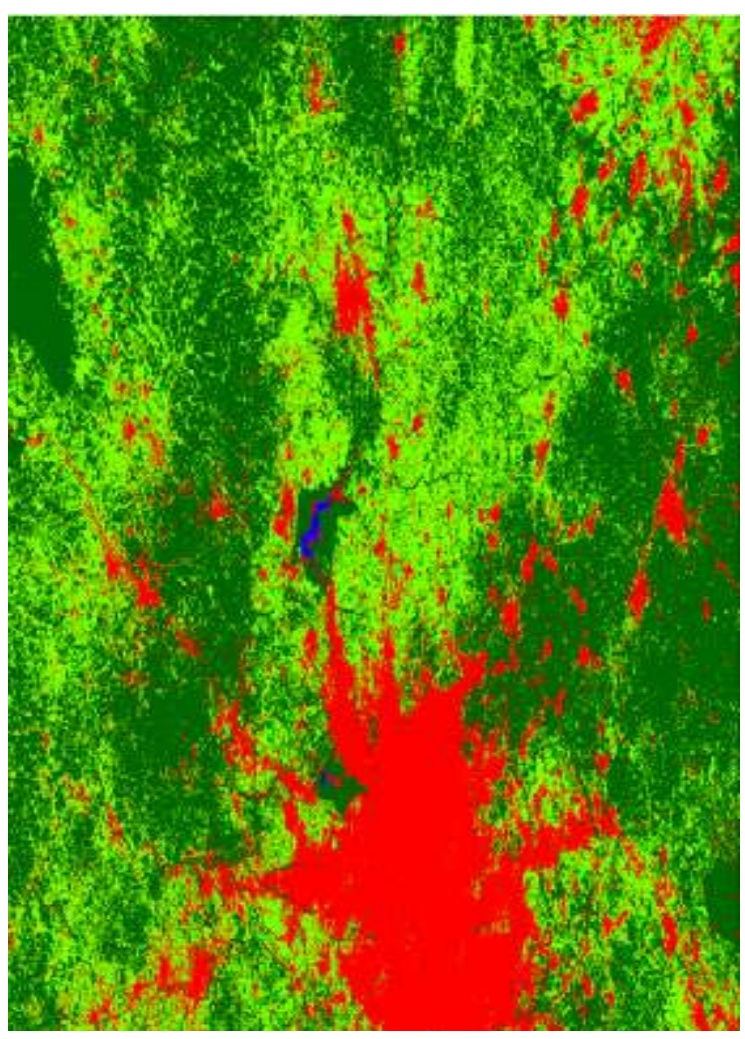

2003

Figure 4. Landsat satellite images showing land cover change of Kumasi between 1986 and 2003

Source: Koranteng (2007) 
Comparison of the two satellite images taken at different times but on the same area (Kumasi) indicated that in 1986 Kumasi was relatively a small city, much of the built environment (red colour) were confined to the centre and had a vast spread of green vegetation (dark green) in all corners of the city. There was also glimpses of agricultural activities (light green) permeating through both the built environment and green vegetation. On the contrary, the 2003 Landsat satellite image exhibited features that depicted a wide land cover change from predominant green vegetation in 1986 to a greater built environment in 2003. Revelations from the 2003 satellite image pointed to the fact that by this time the built environment had quadrupled in size at the expense of the green vegetation as echoed by Koranteng (2007). The city by this time had rapidly expanded outward indicating a high incident of urban sprawl. A study by Cobbinah and Amoako (2012) in Kumasi confirmed this by revealing that urban sprawl have taken up many of the green vegetation of the city. The uncontrolled expansion of the city basically through high rate of housing developments put much strain on many nature reserves and destructed the rich green vegetation that had been preserved over the years to make Kumasi a garden city. The rate of urban sprawl in Kumasi was observed to be very high causing rapid deterioration of green vegetation at the fringes of the city. For example, it was found out that the total land area of Kumasi in 1950 was only $25 \mathrm{~km}^{2}$ but due to rapid urban sprawl the city expanded outward to about $182 \mathrm{~km}^{2}$ in 1963 and as at 2011 the city was estimated to have further expanded beyond its boundaries to cover a land area of about $254 \mathrm{~km}^{2}$ (Poku-Boansi \& Inkoom, 2011). A similar finding came up in a study by Bon (2014) at Melbourne (a garden city in Australia) which found urban sprawl to have caused the city to expand beyond its urban growth boundary since 2006 into the surrounding green vegetation.

To have a clearer picture about the changes in the land cover of Kumasi and also get enough evidence to draw informed conclusions, analysis of different set of Landsat satellite images was made. This time the two block years compared were 1986 and 2007. From the findings of the study it came to the fore that concerning the new Landsat image in 1986, the green vegetation covered approximately $41158.08 \mathrm{ha}(74.08 \%)$ of the total land mass of Kumasi, that of the built environment was about 9533.79ha (17.16\%) whilst the remaining land was shared by other land uses such as agriculture activities, wetlands and water (Tontoh, 2011). The land cover distribution of Kumasi during this time conformed much to the garden city model which Howard (1902) conceptualised to be built on a piece of land with more than half of the total landscape covered by green vegetation. No wonder during this time Kumasi was recognised as the garden city of West Africa and well noted for its beautiful greenery (Quagraine, 2011; Korboe, 2001). A different picture was however observed in the 2007 Landsite satellite image. The opposite of what transpired in 1986 was the situation in 2007 (Figure 5). It was observed that in 2007 a large proportion of the landmass of Kumasi was rather occupied by the built environment (26259.66 hectares, about 47.27\%) (Tontoh, 2011). The green vegetation covered 22513.41 hectares (40.52\%). Figure 5 gives a visual account of the land cover changes observed between 1986 and 2007 with the green vegetation indicated as forest land. 

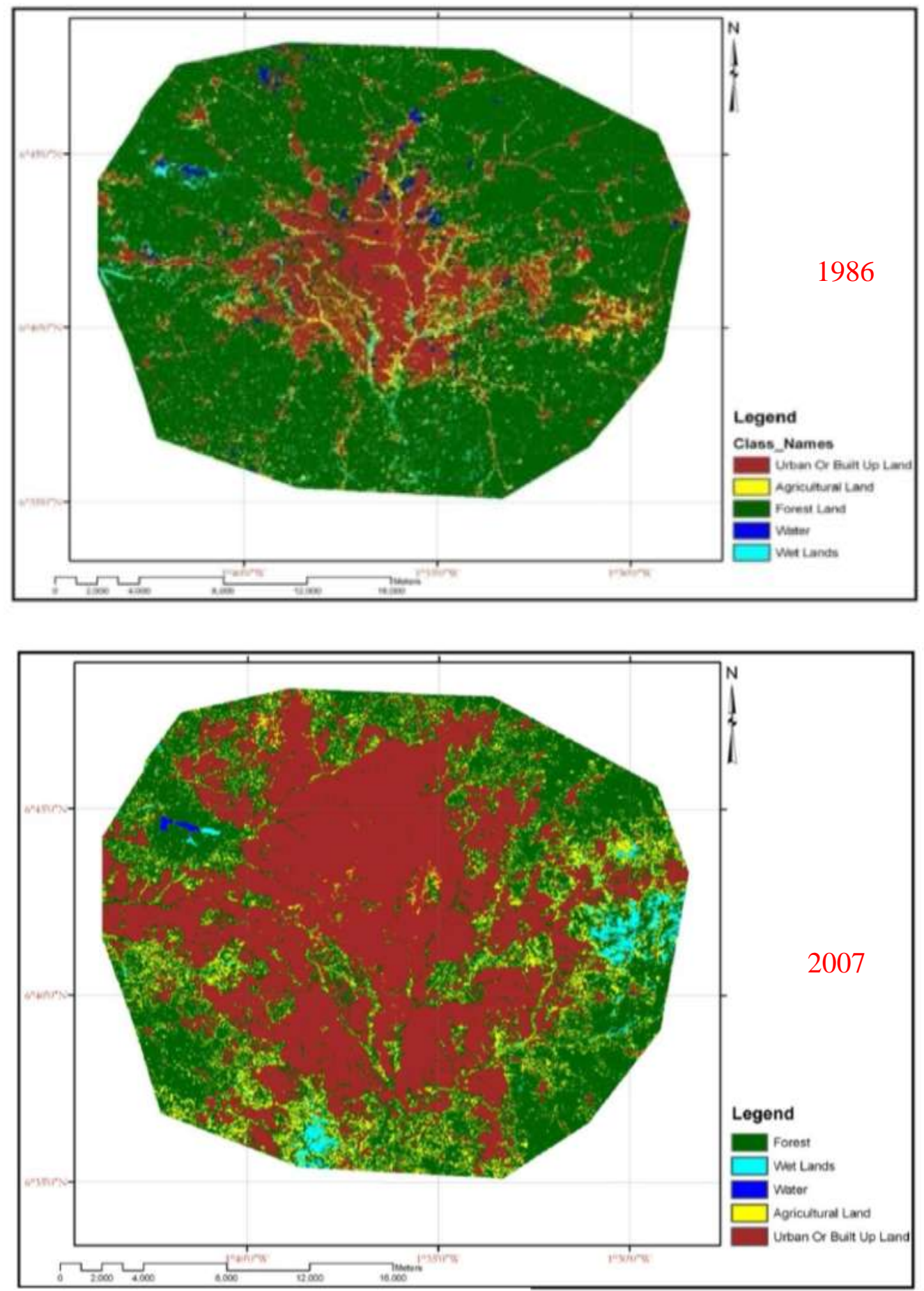

Figure 5. Landsat satellite images showing land cover change of Kumasi between 1986 and 2007

Source: Tontoh (2011)

A further arithmetic analysis of the changes in land cover between the two years (1986 and 2007) under discussion found out that in 2007 the built environment increased by $16,725.87$ hectares of land whilst in contrast the green vegetation reduced by 18,644.67 hectares of land. This finding confirms earlier observation made by Koranteng (2007) about land cover change 
in Kumasi which revealed greater proportion of land been subjected to the built environment land cover type. This revelation defeats the principle of the garden city model which Kumasi was structured on. This is because the excessive built environment in 2007 gave rise to urban sprawl destroying the green belt and several nature reserves that the garden city model frowns upon.

\subsection{Land-Use Trend in Kumasi between 1980 and 2010}

After having a fair idea about Kumasi's land cover changes in broad terms, it became useful to explore further the land-use trend of Kumasi over the years to get additional information on the green vegetation to make necessary deductions. This was done purposely to find out how open spaces which comprises parks, gardens, and other public spaces reserved for human usage have been changing in the land-use structure of Kumasi. Data on land-use distribution or structure of Kumasi from the Town and Country Planning Department, and the Ministry of Land and Natural Resources (2010) were utilised. Table 1 gives a broad overview of the land-use distribution of Kumasi from 1988 to 2010.

Table 1. Land-use distribution of Kumasi from 1988 - 2010

\begin{tabular}{|c|c|c|c|c|c|c|c|c|c|c|}
\hline \multirow[t]{3}{*}{ LAND USE } & \multirow{2}{*}{\multicolumn{2}{|c|}{ 1988* }} & \multirow{2}{*}{\multicolumn{2}{|c|}{1995}} & \multirow{2}{*}{\multicolumn{2}{|c|}{2000}} & \multirow{2}{*}{\multicolumn{2}{|c|}{2005}} & \multirow{2}{*}{\multicolumn{2}{|c|}{2010}} \\
\hline & & & & & & & & & & \\
\hline & $\mathrm{Km}^{2}$ & $\%$ & $\mathrm{Km}^{2}$ & $\%$ & $\mathrm{Km}^{2}$ & $\%$ & $\mathrm{Km}^{2}$ & $\%$ & $\mathrm{Km}^{2}$ & $\%$ \\
\hline Residential & 76.88 & 43.6 & 109.3 & 43.7 & 109.6 & 43.8 & 110.3 & 44.1 & 111 & 44.7 \\
\hline Commercial & 3.88 & 2.2 & 6 & 2.4 & 6 & 2.4 & 6 & 2.4 & 6 & 2.4 \\
\hline Industrial & 7.23 & 4.1 & 10.3 & 4.1 & 10.6 & 4.2 & 10.3 & 4.1 & 10.1 & 4.0 \\
\hline Educational & 32.63 & 18.5 & 43.8 & 17.5 & 43.8 & 17.5 & 43.8 & 17.5 & 43.3 & 17.3 \\
\hline $\begin{array}{l}\text { Civic } \\
\text { Culture }\end{array}$ & 13.75 & 7.8 & 18.8 & 7.5 & 18.8 & 7.5 & 18.1 & 7.3 & 18 & 7.2 \\
\hline Open Space & 19.75 & 11.2 & 28.8 & 11.5 & 28.1 & 11.2 & 28.1 & 11.2 & 27.5 & 10.7 \\
\hline Circulation & 22.21 & 12.6 & 33.1 & 13.3 & 33.1 & 13.3 & 33.4 & 13.4 & 34 & 13.7 \\
\hline Total Area & 176.33 & 100 & 250 & 100 & 250 & 100 & 250 & 100 & 250 & 100 \\
\hline
\end{tabular}

Source: Town and Country Planning of KMA (2010) and Ministry of Lands and Natural Resources (2010)

*Obtained from Ministry of Lands and Natural Resources, and was based only on total planned area at that time.

Analysis of the land-use distribution found an interesting pattern on land allocated to open spaces. Between 1988 and 1995, land allocated to open spaces increased to 11.5 percent of the total land area. This could probably be attributed to the provision made in the 1963-1988 planning scheme to convert substantial portion of the unplanned land reserve of Kumasi to open space development as stressed by Adarkwa \& Owusu-Akyaw (2001). However, it was observed that after 1995 the proportion of open spaces has never increased but rather declined continuously to the tune of 10.7 percent in the present land-use structure of Kumasi (Table 1; Figure 6). This support the findings of Amoako and Korboe (2011) which revealed a 
decreasing trend of open spaces in Kumasi and further found open spaces as one particular land-use that lost the highest proportion of its coverage in the land-use structure of the city in 2010. A further analysis of this trend with the population growth pattern of Kumasi provided a more worrying situation (Figure 6). Between 1984 and 2010, the population of Kumasi increased about 400 percent whilst there was no corresponding increase in open spaces to provide additional public open spaces to cater for the recreational needs of the citizenry.
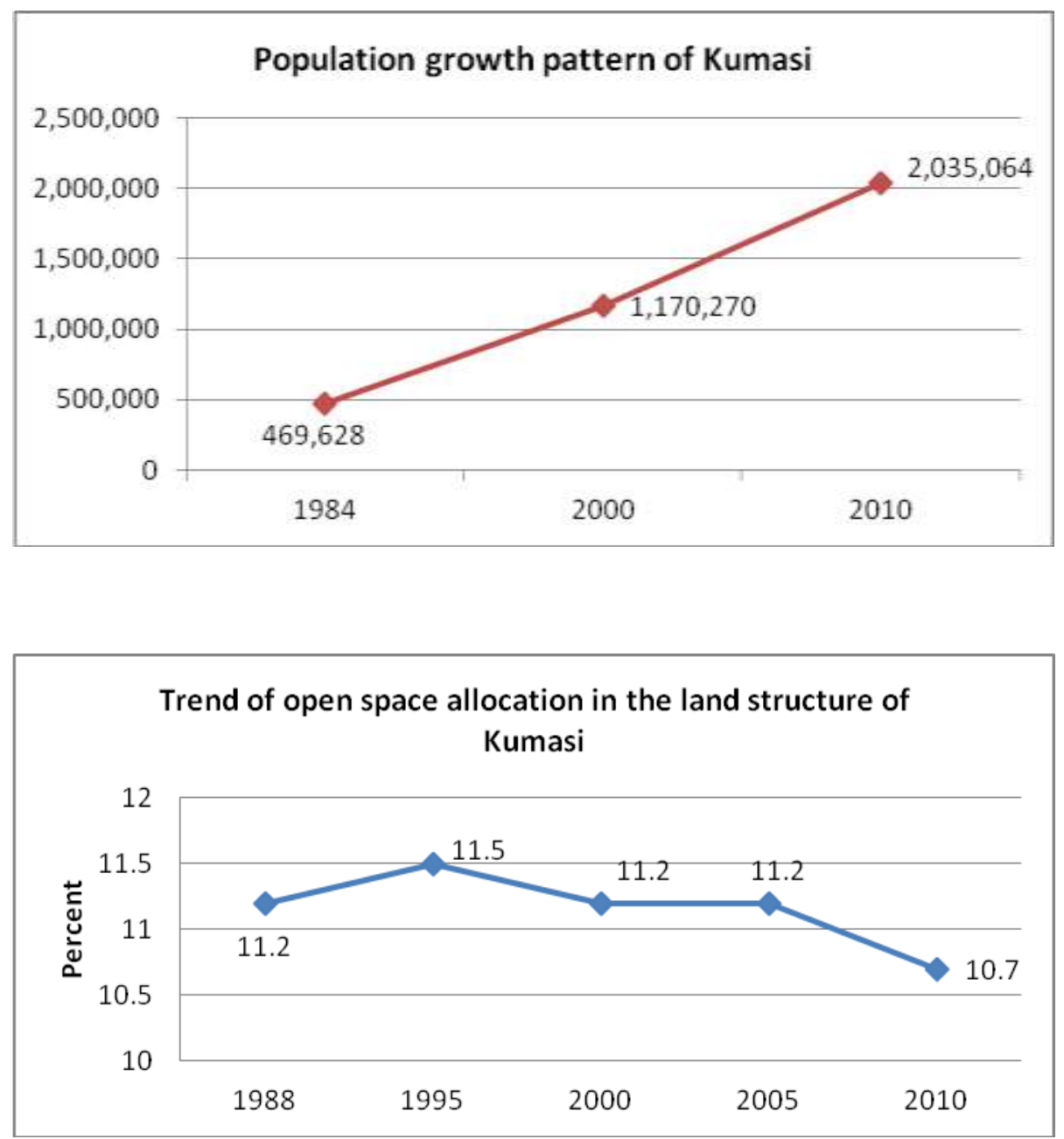

Figure 6. The pattern of open space allocation and population growth of Kumasi

Author's construct (2014)

This indicates that the high human population of Kumasi rely on very limited open spaces for their leisure and recreational activities. This is therefore not the best as it does not create room for easy access to public open spaces and also discourages many outdoor play activities that the garden city model supports.

\subsection{The Current Situation of Parks and Gardens}

An important aspect of the garden city model is the integration of many parks and gardens into a city's landscape. In line with this, an assessment of the available public parks and gardens in Kumasi was done. This was done through personal observations and review of the 
available materials on the matter. It was found out of that most of the public parks and gardens are either not in existence or have large portions encroached upon for commercial activities and infrastructural developments. For example, a study by Asare (2013) found many parks in Kumasi to have been converted into commercial centres with the Prince of Wales Park and Kotoko Park (Cricket) being notable examples. Similarly, Adjei Mensah (2014) found substantial portion of the Fante Newtown Park encroached for commercial activities. The Para Gardens was also found to have been taken over by the "Sofoline" interchange. The Kumasi Zoo and KNUST Botanical Gardens were observed to be the only places that still attract many visitors for various recreational purposes. Table 2 gives a detail account of the status of major parks and gardens in Kumasi.

Table 2. The state of some parks and gardens in Kumasi

\begin{tabular}{|l|l|l|}
\hline Park/Garden & Location & Status \\
\hline Para Gardens & $\begin{array}{l}\text { South Suntreso } \\
\text { Neighbourhood }\end{array}$ & Not in existence \\
\hline Prince of Wales Park & $\begin{array}{l}\text { Adjacent the Kumasi } \\
\text { Zoological Gardens }\end{array}$ & Not in existence, now use a lorry park \\
\hline Adehyeman Gardens & $\begin{array}{l}\text { Near Methodist } \\
\text { Bookshop, Mbrom }\end{array}$ & $\begin{array}{l}\text { In operation but large portions have been encroached } \\
\text { for commercial activities }\end{array}$ \\
\hline Kumasi Zoo & $\begin{array}{l}\text { Adjecent Kejetia lorry } \\
\text { terminal }\end{array}$ & In operation \\
\hline KNUST Botanical Garden & At KNUST campus & In operation \\
\hline Parks and Gardens & Patasi Neighbourhood & Not open for public usage \\
\hline Kumasi Children's Park & $\begin{array}{l}\text { Amakom } \\
\text { Neighbourhood }\end{array}$ & Abandoned to lose all its facilities \\
\hline Abbey's Park & $\begin{array}{l}\text { Ash Town } \\
\text { Neighbourhood }\end{array}$ & Abandoned to lose all its facilities \\
\hline Jacksons Park & $\begin{array}{l}\text { Close to Prempeh } \\
\text { Assembly Hall }\end{array}$ & No more a natural park \\
\hline Fante Newtown Park & $\begin{array}{l}\text { Fante Newtown } \\
\text { Neighbourhood }\end{array}$ & Encroached upon for commercial activities \\
\hline Kotoko Park (Cricket) & $\begin{array}{l}\text { Behind Manhyia } \\
\text { Hospital }\end{array}$ & Not in existence \\
\hline Addo's Park & $\begin{array}{l}\text { Behind Manhyia } \\
\text { Palace }\end{array}$ & Not in existence \\
\hline Dogo Moro Park & $\begin{array}{l}\text { Asewase } \\
\text { Neighbourhood }\end{array}$ & Encroached upon for commercial activities \\
\hline
\end{tabular}

Source: Fieldwork (2013) and Asare (2013)

The declining and deplorable nature of the parks and gardens was found to be as a result of factors such as poor enforcement of development controls by the city authorities, uncooperative attitudes of the general public, lack of comprehensive plan for green spaces, lack of priority to green spaces and conflicting land ownership rights over green spaces (Adjei Mensah, 2014; Oduro-Ofori \& Braimah, 2013; Taylor 2010). Personal observations of some of the parks in Kumasi to get first-hand information found a bizarre situation and a clear demonstration of little or no attention given to green paces (Figure 7). It was observed that many parks were ignored by the city authorities with the general public misusing these parks for different activities to satisfy their selfish interests. The end results have been 


\section{Macrothink}

Journal of Environment and Ecology

ISSN 2157-6092

2014, Vol. 5, No. 2

unhealthy physical condition and poor nature of many parks which deter people from using such spaces.

1
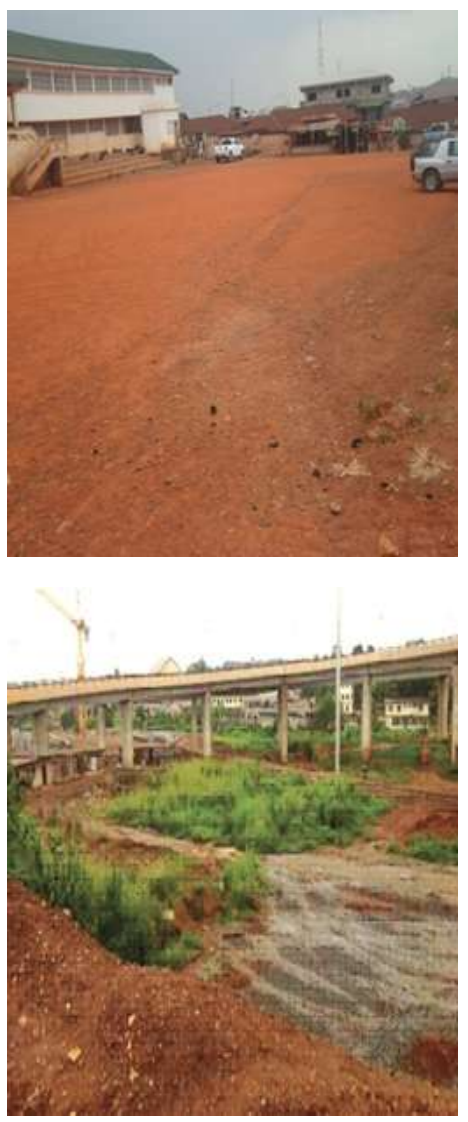

4
2
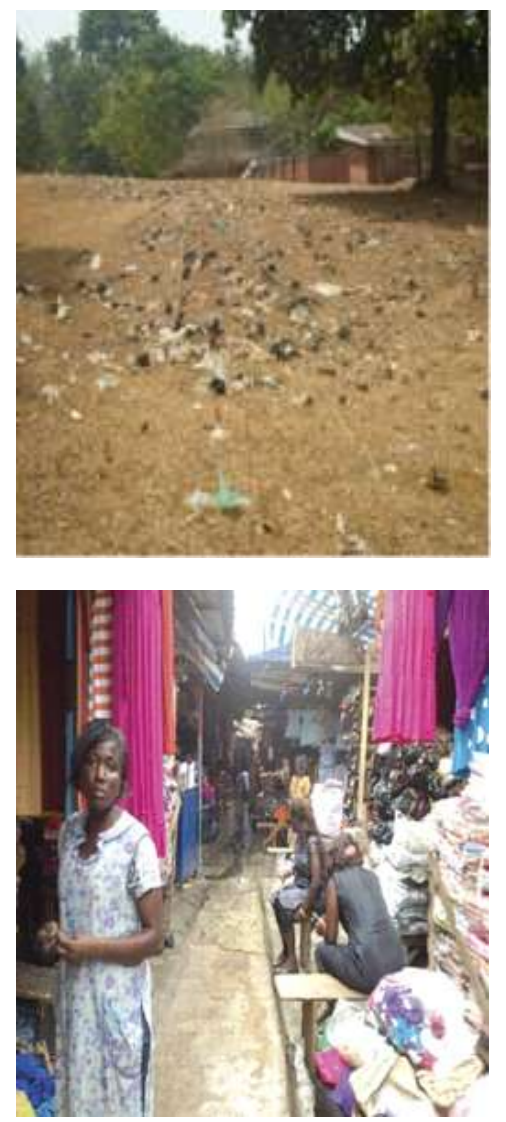

5
3
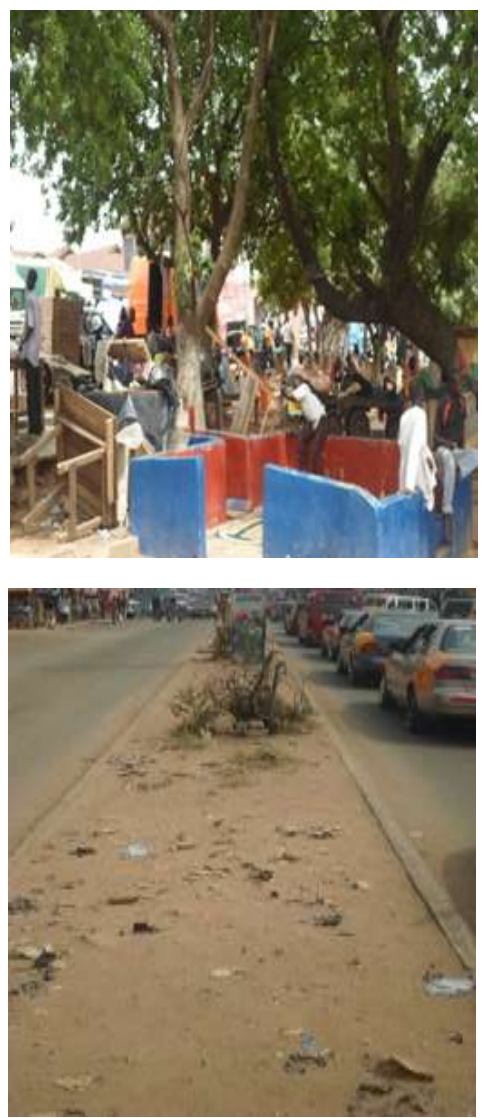

6

Figure 7. The condition of some parks and gardens in Kumasi

Source: Fieldwork (2013) and Asare (2013)

1: Abbeys Park with no grass and facilities

2: Abandoned Kumasi Children's park with poor hygienic condition

3: Aspect of Fante Newtown Park converted into a commercial centre

4: Para Gardens taken over by the construction of "Sofoline" interchange

5: Part of Adehyeman Gardens encroached for commercial activities

6. Shrubs along the road at "Neoplan station" destroyed and used as pedestrian walkways.

In a related development, the demarcated green belt for the city was found to be no more. Studies by Quagraine (2011) revealed that the green belt of Kumasi which stretched through neighbourhoods such as Atonsu, Kaasi, Bantama, Aboabo has now become vacant as most of this green belt have been converted into housing developments. This corroborates the findings of Koranteng and Zawila-Niedzwiecki (2008) which linked the excessive loss of the green vegetation of Kumasi to deforestation caused predominantly by lateral expansion of human settlements.

A calculation of per capita green space of Kumasi by Adjei Mensah (2013) found Kumasi to 
have about $4.7 \mathrm{~m}^{2}$ green space per capita. This condition is far below the standard per capita green space recommended by WHO to enable a city have enough green spaces for its dwellers which is $9 \mathrm{~m}^{2}$ (Faudy \& Darjosanjot, 2012; Singh et al., 2010; Thaiutsa et al., 2008). Furthermore, many urban trees which were very conspicuous in the physical landscape of the city and formed canopies along the principal streets of Kumasi have been depleted. It came out that the tree canopy cover of Kumasi now stand at 7 percent of the total land area (Quagraine, 2011) but it was over 15 percent in the 1970's and 1980's. This indicates that more than 100 percent of urban trees in Kumasi have been lost, causing most of the streets not to have trees along them. A study by Oduro-Ofori \& Braimah (2013) revealed that about 60 percent of the streets in Kumasi do not have trees along them. This condition is contrary to the garden city model which requires streets in cities to be lined with many trees. This situation suggests that Kumasi now has very limited green spaces to cater for the recreational needs of the residents.

\section{Conclusion}

In sum, based on the findings of the paper, Kumasi can be said to have lost its garden city status from the perspective of green vegetation. It has limited green vegetation and for that matter green spaces to meet the recreational needs of the people. Excessive urban sprawl has caused the city to merge with its surrounding villages and hence destroy most of the preserved green vegetation at the fringes of the city. Problems of absence of green belts and lack of parks, gardens and urban trees to satisfy the recreational and health needs of the residents were prevalent. All these findings deviates from the green vegetation component of the garden city model which required a preserved green belt to prevent cities from expanding outward, availability of many parks and gardens, and overall substantial portion of city's land mass occupied by green vegetation. For Kumasi to regain much of its lost green vegetation, a committed effort by the city authorities in collaboration with major environmental stakeholders and the local people shall be needed to strictly enforce the available land-use regulation to control undue encroachment of the green vegetation. Conservation of the green vegetation in Kumasi should also be made a priority by the city authorities with appropriate green space strategy put in place to guide the overall development and management of the green vegetation.

\section{Acknowledgement}

I want to use this opportunity to thank my colleague at the University of Birmingham (UK), Upuli Perera for her constructive suggestions during the early stages of this master piece when I was gathering ideas about how to structure the paper.

\section{References}

Adarkwa, K. K., \& Owusu-Akyaw (2001). Development control in Kumasi. In K. K. Adarkwa, \& J. Post. (Eds.), The fate of the tree: Planning and managing the development of Kumasi, Ghana (pp. 199 - 208). Accra; Woeli Publishing Services.

Adjei Mensah, C. (2013). What is the state of green spaces in your city? Insights from Kumasi city. Paper presented at the Doctoral Researcher Conference at University of 
Birmingham (UK), December $17-18$.

Adjei Mensah, C. (2014). Destruction of urban green spaces: A problem beyond urbanisation in Kumasi city. American Journal of Environmental Protection, 3(1), 1-9. http://dx.doi.org/ 10.11648/j.ajep.20140301.11

Amoako, C., \& Korboe, D. (2011). Historical development, population growth and present structure of Kumasi. In Adarkwa, K. K. (Ed.), Future of the tree: Towards growth and development of Kumasi (pp. 35 -54). Kumasi: University Printing Press.

Asare, G. E. (2013). Kumasi: The garden city without gardens. [Online] Available http:/graphic.com.gh/features/features/10748-kumasi-the-garden-city-without-gardens.html (May 2, 2014)

Bon, M. (2014). Melbourne: Garden city, part 4 - urban sprawl issues. (Online) Available http://www.constructionshows.com/melbourne-garden-city-part-4-urban-sprawl-issues-2/021 0802 (August 25, 2014).

Clark, B. (2003). Ebenezer Howard and the marriage of town and country: An introduction to Howard's Garden Cities of To-morrow (Selections). Organisation and Environment, 16, 87-97. http://dx.doi.org/10.1177/1086026602250258

Cobbinah, P. B., \& Amoako, C. (2012). Urban sprawl and loss of peri-urban land in Kumasi, Ghana. International Journal of Social and Human Sciences, 6, 388-397.

Corovic, D. (2009). The garden city concept: From theory to implementation. SAJ, 1, 65-80.

Curtin, P. (1992). Medical knowledge and urban planning in colonial tropical Africa. In S. Feierman, \& J. Janzen (Eds), Social basis of health and healing in Africa (pp.235 - 255). Berkeley: University of California Press).

Dinye, R., Edusei, J., \& King, R. S. (1987). District resources development handbook: Kumasi District. Kumasi: Department of Housing and Planning Research, University of Science and Technology.

Fam, D., Mosley, E., Lopes, A., Mathieson, L., Morison, J., \& Connellan, G. (2008). Irrigation of urban green spaces: A review of the environmental, social and economic benefits. CRC for Irrigation Futures Technical Report No. 04/08.

Faudy, M., \& Darjosanjot, E. T. S. (2012). Tropical ecological city concept for Banda Aceh to become sustainable after Tsunami disaster. Journal of Applied Environmental and Biological Sciences, 2(8), 428-433.

Fuller, R. A., \& Gaston, K. J. (2009). The scaling of green space coverage in European cities. Biology Letters, 5(3), 352- 355. http://dx.doi.org/10.1098/rsbl.2009.0010

Ghana Statistical Service. (2012). The 2010 Population and Housing Census: Population by sex, region and district. Accra: Ghana Statistical Service.

Goddard, M. A., Dougill, A. J., \& Benton, T. G. (2010). Scaling up from gardens: 
Biodiversity conservation in urban environments. Trends in Ecology \& Evolution, 25, 90-98.

Hall, P. (2002). Urban and regional Planning (4 ${ }^{\text {th }}$ ed.). Routledge: London and New York.

Harris, G. M. (1906). The garden city movement. London: Garden City Association.

Howard, E. (1902). Garden cities of to-morrow. London: Swan Sonnenschein \& Co.

Kabisch, N., \& Haase, D. (2014). Green justice or just green? Provision of urban green spaces in Berlin, Germany. Landscape and Urban Planning, 122, 129-139.

Koranteng, A. (2007). The study of the land Use/cover of Kumasi and its environs using Landsat images.

Koranteng, A., \& Zawila-Niedzwiecki, T. (2008). Monitoring of deforestation in Kumasi area (Ghana) by satellite based multi-temporal land use analysis. Roczniki Geomatyki, VI(8), 71-84.

Kumasi Metropolitan Assembly. (2010). Kumasi development plan (2010 -2013). Kumasi: Kumasi Metropolitan Assembly.

Ministry of Lands and Natural Resources (2010). Land Administration Project (LAP) II: Proposed office building in Kumasi. Accra: Environ Engineering \& Management Consult.

Mumford, L. (1972). The garden city idea and modern planning. In E. Howard (Ed.), Garden cities of to-morrow(pp. 29-40). Cambridge, MA: MIT Press

Oduro-Ofori, E., \& Braimah, I. (2013). Where is the green infrastructure in the garden city of West Africa, Kumasi? Paper presented at the international conference on smarter cities. Manila, 14-15 November.

Poku-Boansi, M., \& Inkoom, D. K. B. (2011). Urbanisation and human security in the Kumasi Metropolis. In Adarkwa, K. K. (Ed.), Future of the tree: Towards growth and development of Kumasi (pp.234-248). Kumasi: University Printing Press.

Quagraine, V. K. (2011). Urban landscape depletion in the Kumasi Metropolis. In K. K. Adarkwa (Ed.), Future of the tree: Towards growth and development of Kumasi (pp. 212 233). Kumasi: University Printing Press.

Sandstrom, U. G. (2009). Urban green spaces for human well-being. A paper presented at the $29^{\text {th }}$ annual conference of International Association for Impact Assassment. Accra, Ghana, 16-22 May.

Schmidt, S. (2005). Cultural influences and the built environment. An examination of Kumasi, Ghana. Journal of Urban Design, 10(5), 353-370.

Singh, V. S., Pandey, D. N., \& Chaudry, P. (2010). Urban forests and open green spaces: Lessons for Jaipur, Rajasthan, India. RSPCB Occasional Paper No. 1. Rajasthan: Rajasthan State Pollution Control Board.

Taylor, P. (2010). Improving children's park in Kumasi. Master's thesis, Department of 


\section{Macrothink}

Architecture, Kwame Nkrumah University of Science and Technology, Kumasi.

Thaiutsa, B., Puangchit, L., Kjelgren, R., Arunpraparut, W. (2008). Urban green space, street tree and heritage large tree assessment in Bangkok, Thailand. Journal Urban Forestry \& Urban Greening, 7, 219-229. http://dx.doi.org/10.1016/j.ufug.2008.03.002

Tontoh, A. G. (2011). A study to ascertain the growth situation of the Kumasi Metropolitan area (KMA): A remote sensing approach. Master's thesis, Department of Geomatic Engineering, Kwame Nkrumah University of Science and Technology, Kumasi.

Town and Country Planning Association (2014). The TCPA garden city principles. London: Town and Country Planning Association.

Town Planning Memorandum (1951). Ashanti Regional archives, Kumasi. Accra, $19^{\text {th }}$ December.

United Nations (2012). World urbanization prospects: The 2011 revision. New York, NY: United Nations.

Ward, S. V. (1992). The garden city: Past, present and future. London: E and FN Spon.

Woodside, A. G. (2010). Case study research: Theory, methods and practice. Bingley: Emerald Group Publishing Limited.

Yin, R. K. (2003). Case study research: Design and methods ( $3^{\text {rd }}$ ed.). Thousand Oaks: Sage Publications.

Yin, R. K. (2009). Case study research: Design and methods ( $4^{\text {th }}$ edi.). Thousand Oaks: Sage Publications. 